\title{
HIV Viral Load PCR Measurement
}

National Cancer Institute

\section{Source}

National Cancer Institute. HIV Viral Load PCR Measurement. NCI Thesaurus. Code C74727.

The determination of the HIV viral load in a specimen using polymerase chain reaction. 